\title{
コンクリート中の鉄筋腐食速度に及ぼす各種要因の影響 に関する長期屋外暴露実験 \\ LONG-TERM OUTDOOR EXPOSURE TEST ON THE RATE OF CORROSION OF REINFORCING BAR IN CONCRETE CONTAINING CHLORIDE ION
}

\author{
掛川勝*1, 栘田佳寛*2, 松林裕二*3, 鹿毛忠継*4 \\ Masaru KAKEGAWA, Yoshihiro MASUDA, Yuji MATSUBAYASHI \\ and Tadatsugu KAGE
}

\begin{abstract}
This paper reports the results of long-term outdoor exposure test on the rate of corrosion of reinforcing bar in concrete which contains chloride ion. The factor of experiment are sodium chloride content ( $0 \sim 1.0 \% /$ sand), water-cement ratio ( $50 \sim 65 \%)$, and thickness of concrete cover $(15 \sim 40 \mathrm{~mm})$.It is concluded as follows, The corrosion loss of reinforcing bar in long-term outdoor exposure test increases in proportion to square root of exposure period. Rate of corrosion of reinforcing bar decreases with increasing thickness of concrete cover in sodium chloride content $(0 \sim 0.3 \% /$ sand). The estimation equation of the rate of corrosion of sodium chloride content $(0 \sim 1.0 \% /$ sand $)$ are proposed by thickness of concrete cover and water- cement ratio.
\end{abstract}

\author{
Keywords : long-term outdoor exposure test, rate of corrosion, corrosion loss, sodium chloride content, water- cement ratio, \\ concrete cover \\ 長期屋外暴露実験, 腐食速度, 質量減少, 塩分量, 水セメント比, かぶり厚さ
}

\section{1. はじめに}

鉄筋コンクリート造建築物の物理的な耐用年数を評価するために は、コンクリートの劣化や鉄筋腐食に及ぼす各種要因の定量的把握 が必要である。このうち、鉄筋腐食の原因としては、コンクリート の中性化やコンクリートに含まれる塩化物イオンの影響が考えられ る。コンクリート中に含まれる塩化物イオンは、洗浄が不十分であ った海砂の使用やコンクリートの硬化促進剤に含まれる塩化物イオ ンによる、いわゆる内在塩化物イオンと海岸地域あるいは融雪剤を 使用する地域において建築物が竣工後に、外部から塩化物イオンが 浸入する、いわゆる外来塩化物イオンに分けられる。

コンクリート中に含まれる塩化物イオンが鉄筋腐食速度に及ぼす 影響については、これまで多くの調查、研究が行われ、かなり明ら かにされてきている ${ }^{3-6)}$ 。筆者らは、かぶり厚さを変えて鉄筋を埋込 んだコンクリート試験体の高温多湿条件での腐食促進実験および 9 年間自然環境下で暴露実験を行った場合の塩化物イオンを含んだコ ンクリート中の鉄筋腐食量の変化や腐食速度について検討し、コン クリートのかぶり厚さ、水セメント比およびコンクリート中の塩化
物イオン量の関数として表すことができると報告した 7-8)。

しかし、10 年以上の長期にわたる塩化物イオンを含んだコンクリ 一ト中の鉄筋腐食量や腐食速度については、十分明らかでない。こ のようなことから、本報告では、既報 8)の 9 年間の暴露実験以降に、 継続して実施してきた塩化物イオン量、水セメント比およびかぶり 厚さを変化させて鉄筋を埋込んだコンクリート試験体の 20 年まで の暴露試験の結果を紹介寸るものであり、コンクリートの品質やコ ンクリート中に含まれる塩化物イオン量が鉄筋の腐食速度に及ぼす 影響について定量的に評価するものである。

\section{2. 実験方法}

\section{1 実験計画}

（1）鉄筋腐食要因

塩化物イオンを含んだコンクリート中の鉄筋腐食に影響を及ぼす 要因として、水セメント比に代表されるコンクリート品質、かぶり 厚さおよび塩化物イオン量を取りあげた。また、一般の建築物にお けるコンクリートの中性化進行の状況をシミュレートするため、あ

本報告は，参考文献 1)，2）を基に，デー夕を見直し，再解析したものである。

*1 太平洋マテリアル株開発研究所 丁修

*2 宇都宮大学工学研究科地球環境デザイン学専攻 教授. 工博

*3 太平洋マテリアル(株)開発研究所 博士 (工学)

*4 独立行政法人建築研究所 博士 (学術)

R \& D Lab., Taiheiyo Materials Corporation, M. Eng.

Prof., Dept. of Design and Engineering for Global Environment, Architecture Course, Utsunomiya University, Dr. Eng.

R \& D Lab., Taiheiyo Materials Corporation, Ph. D.

Building Research Institute, Ph. D. 
らかじめ促進試験によって試験体の表面から約 $15 \mathrm{~mm}$ まで中性化 させた。ただし、水セメント比 $50 \%$ の試験体は実際の状況を考慮し、 かつ促進中性化試験の時間の関係もあって約 $10 \mathrm{~mm}$ までとした。

実験の要因と水準を表 1 に、添加した塩分量のレベル（以下、塩 分量のレベル）と水セメント比の組合わせを表 2 に示す。塩分量の レベルは、洗浄が不十分な海砂を用いた場合に、砂からコンクリー 卜に導入される塩分量に関する実態調査を基に定めたものであり、

$\mathrm{NaCl}$ を砂質量比（\%) で表したものである。塩分量のレベル $1.0 \%$ は、実態調査 $\left.{ }^{5}\right)$ におけるほぼ最大の塩分量を想定している。

\section{(2) 実験手順 8)}

実験の手順は、図 1 に示寸コンクリートを打ち込んだ試験体を材 齢 2 日で脱型し、材齢 3 週まで湿布散水養生、材齢 4 週まで温度 $20^{\circ} \mathrm{C} 、$ 湿度 $60 \%$ R.H.の恒温恒湿室で保存し、その間に試験体の両側面を除 く上下面および両端面をエポキシ樹脂でシールした。その後、温度 $30^{\circ} \mathrm{C}$ 、湿度 $60 \% \mathrm{RH} 、 \mathrm{CO}_{2}$ 濃度 $5 \%$ の条件で中性化促進を行った。

中性化の進行状況は、同じ水セメント比のモニター用の試験体を 順次切断して調べた。水セメント比が $55 \%$ \% $65 \%$ の試験体について は、モニター用試験体の中性化深さが $15 \mathrm{~mm}$ に達した時点で中性化 促進試験槽から試験体を取り出し、暴露試験の開始まで温度 $20^{\circ} \mathrm{C}$ 、 湿度 $60 \%$ R.H.の恒温恒湿室に保存した。また、水セメント比が $50 \%$ の試験体については、水セメント比 $55 \%$ の試験体と同時期に取り出 した。水セメント比 $50 \%$ の試験体の中性化深さは平均 $10 \mathrm{~mm}$ 程度 であった。

中性化促進試験の期間は約 8 カ月間であったが、途中促進試験機 の故障で中断した期間があり、水セメント比 $50 \%$ および $55 \%$ の場 合の促進中性化期間は 6 力月であった。なお、促進中性化試験機に 入っていない期間は恒温恒湿室に保存した。

屋外暴露試験は、材齢約 9 カ月から茨城県つくば市の建築研究所 の屋外暴露試験場で行い、暴露期間 2，4，9、15 および 20 年でそ れぞれ 1 体ずつ試験体を解体し、鉄筋腐食の評価を行った。なお、

2,4 および 9 年での計測結果は既に報告 8) しているが、今回、15 および 20 年の結果を加え、すべての結果を基に再評価した。暴露 地域の環境は、気象庁つくば（館野）の気象データ $(1981 〜 2010) に$ よると、平均気温 $13.8^{\circ} \mathrm{C}$ 、平均湿度 $75 \%$ R.H.、年間降水量 1282.9 $\mathrm{mm}$ 、日照時間 $1912.8 \mathrm{~h}$ 、全天日射量 $13.1 \mathrm{MJ} / \mathrm{m}^{2}$ である。

\section{2 使用材料およびコンクリートの性質}

\section{(1) 鉄 筋}

鉄筋は、JIS G 3112 (鉄筋コンクリート用棒鋼) の SR24（実験 当時）の規格品で、 $\phi 13 \mathrm{~mm}$ の丸鋼を用いた。鉄筋は酸化被膜（黒 皮)付であり、コンクリート打込み前にアセトンで脱脂して用いた。

(2) コンクリートの材料

コンクリートの材料は以下の通りである。

(1) セメント：普通ポルトランドセメント（塩化物イオン量 $0.005 \%)$

(2) 細骨材: 川砂 (産地: 大井川、絶乾比重 2.58 、吸水率 $1.42 \%$ 、 粗粒率 2.72)

(3) 粗骨材: 砕石（産地: 青梅、絶乾比重 2.62 、吸水率 $0.73 \%$ 、 粗粒率 6.76)

(4) 練混ぜ水: 水道水（塩化物イオン量 $80 \mathrm{ppm}$ )
表 1 実験の要因と水準

\begin{tabular}{|c|c|}
\hline 要 因 & 水 \\
\hline $\begin{array}{c}\text { 添加した塩分量のレベル } \\
(\mathrm{NaCl} \text { 砂質量，\%) }\end{array}$ & $\begin{array}{lllll}0, & 0.1, & 0.3, & 0.5, & 1.0\end{array}$ \\
\hline 水セメント比（\%) & $50,55,60,65$ \\
\hline かぶり厚さ（mm） & $15,20,30,40$ \\
\hline
\end{tabular}

表 2 添加した塩分量のレベルと水セメント比の組合せ

\begin{tabular}{c|c|c|c|c|c}
\hline \multirow{2}{*}{$\begin{array}{l}\text { 水セメント } \\
\text { 比 }\end{array}$} & \multicolumn{5}{|c}{ 添加した塩分量のレベル $(\mathrm{NaCl}$ /砂質量, \%) } \\
\cline { 2 - 6 }$(\%)$ & 0 & 0.1 & 0.3 & 0.5 & 1.0 \\
\hline \hline 50 & - & $\bigcirc$ & $\bigcirc$ & $\bigcirc$ & $\bigcirc$ \\
\hline 55 & - & $\bigcirc$ & $\bigcirc$ & $\bigcirc$ & $\bigcirc$ \\
\hline 60 & $\bigcirc$ & $\bigcirc$ & $\bigcirc$ & $\bigcirc$ & - \\
\hline 65 & $\bigcirc$ & $\bigcirc$ & $\bigcirc$ & $\bigcirc$ & - \\
\hline
\end{tabular}

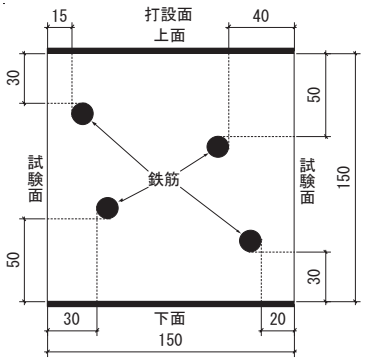

図 1 試験体の形状・ 寸法

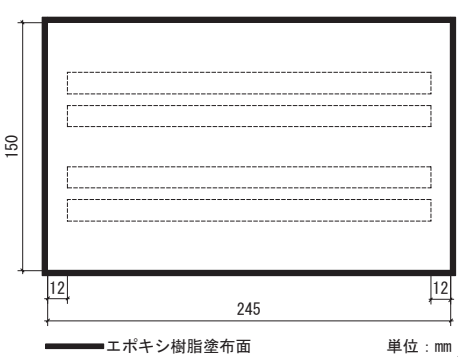

(5) 混和剤： $\mathrm{AE}$ 剂 (レジン系)

(6) 塩分量調整試薬 : $\mathrm{NaCl}$ (一級試薬)

（3）コンクリートの調合および性質

コンクリートの調合と性質を表 3 に示す。なお、表 3 では、塩分 量のレベルとともに、塩化物イオン量を示した。塩分量のレベルは、 絶乾の細骨材量に対する質量比として定めたため、添加した塩化物 イオン量は調合において異なっている。また、供給される塩化物イ オン量は、水から $0.015 \mathrm{~kg} / \mathrm{m}^{3}$ 、セメントから $0.014 \sim 0.018 \mathrm{~kg} / \mathrm{m}^{3}$ であり、およそ $0.03 \mathrm{~kg} / \mathrm{m}^{3}$ である。

\section{3 評価項目}

(1)コンクリート表面の観察

コンクリート試験体を解体する前に、目視でひび割れの有無を調 ベ、さらに、クラックスケールでひび割れ幅を測定した。

(2)鉄筋の発錆面積率

トレーシングペーパーに錆の状況を複写し、錆の部分をすべて黒 く塗りつぶして、面積自動測定装置を用いて発錆面積を測定し、発 錆面積率を算出した。

(3)鉄筋の質量減少率

クエン酸 2 アンモニウム水溶液により鉄筋の錆落しを行い、鉄筋 質量 $\mathrm{W}$ を測定し、最初の質量 $\mathrm{W}_{0}$ からの減少量を求め、式(1)を用い て質量減少率を算出した。鉄筋の質量の測定は電子天秤を用いて $0.01 \mathrm{~g}$ まで測定した。 
表 3 コンクリートの調合と性質

\begin{tabular}{|c|c|c|c|c|c|c|c|c|c|}
\hline \multirow{2}{*}{$\begin{array}{c}\text { 水セメント比 } \\
(\%)\end{array}$} & \multirow{2}{*}{$\begin{array}{c}\text { 添加した塩分 } \\
\text { 量のレベル*1 } \\
\text { (NaCl/砂質量 } \\
\text { 比, \%) }\end{array}$} & \multicolumn{4}{|c|}{ 単位量 $\left(\mathrm{kg} / \mathrm{m}^{3}\right)$} & \multirow{2}{*}{$\begin{array}{c}\text { 添加塩化物 } \\
\text { イオン量 } \\
\left(\mathrm{Cl}^{-}\right) \\
\left(\mathrm{kg} / \mathrm{m}^{3}\right) \\
\end{array}$} & \multirow[b]{2}{*}{$\begin{array}{c}\text { スランプ } \\
(\mathrm{cm})\end{array}$} & \multirow[b]{2}{*}{ 空気量 (\%) } & \multirow{2}{*}{$\begin{array}{c}\text { 圧縮強度 } \\
\text { 材齢 } 28 \text { 日 } \\
\left(\mathrm{N} / \mathrm{mm}^{2}\right)\end{array}$} \\
\hline & & セメント & 水 & 細骨材 & 粗骨材 & & & & \\
\hline \multirow{4}{*}{50} & 0.1 & \multirow{4}{*}{370} & \multirow{16}{*}{185} & \multirow{4}{*}{769} & \multirow{4}{*}{972} & 0.45 & 17.0 & 4.8 & 40.6 \\
\hline & 0.3 & & & & & 1.36 & 17.0 & 4.6 & 40.8 \\
\hline & 0.5 & & & & & 2.27 & 16.5 & 4.6 & 40.4 \\
\hline & 1.0 & & & & & 4.54 & 16.0 & 4.1 & 41.3 \\
\hline \multirow{4}{*}{55} & 0.1 & \multirow{4}{*}{336} & & \multirow{4}{*}{798} & \multirow{4}{*}{972} & 0.47 & 18.5 & 4.5 & 34.6 \\
\hline & 0.3 & & & & & 1.40 & 18.0 & 4.8 & 34.6 \\
\hline & 0.5 & & & & & 2.34 & 17.5 & 4.5 & 34.5 \\
\hline & 1.0 & & & & & 4.68 & 17.5 & 4.2 & 35.5 \\
\hline \multirow{4}{*}{60} & 0.0 & \multirow{4}{*}{308} & & \multirow{4}{*}{827} & \multirow{4}{*}{966} & 0.00 & 19.0 & 4.7 & 28.4 \\
\hline & 0.1 & & & & & 0.49 & 18.5 & 4.5 & 28.5 \\
\hline & 0.3 & & & & & 1.47 & 18.0 & 4.3 & 28.8 \\
\hline & 0.5 & & & & & 2.44 & 17.5 & 4.4 & 28.0 \\
\hline \multirow{4}{*}{65} & 0.0 & \multirow{4}{*}{285} & & \multirow{4}{*}{872} & \multirow{4}{*}{940} & 0.00 & 19.0 & 4.7 & 24.7 \\
\hline & 0.1 & & & & & 0.52 & 18.5 & 4.6 & 23.7 \\
\hline & 0.3 & & & & & 1.55 & 18.5 & 4.8 & 23.5 \\
\hline & 0.5 & & & & & 2.58 & 17.5 & 5.0 & 25.3 \\
\hline
\end{tabular}

*1 細骨材の絶乾重量に対する百分率

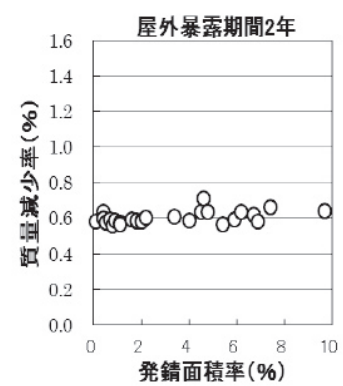

発錆面積率(\%)

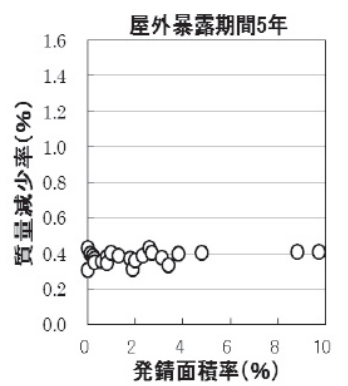

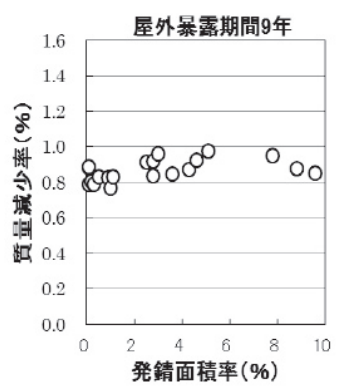

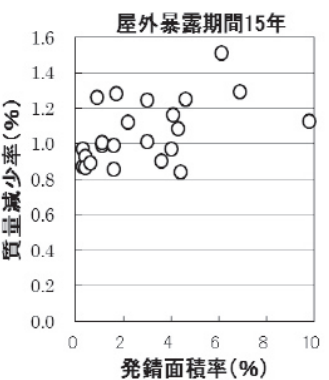

図 2 各屋外暴露期間における発錆面積率と質量減少率の関係

$\Delta \boldsymbol{w}_{0}=\left\{\left(\mathrm{W}_{0}-\mathrm{W}\right) / \mathrm{W}_{0}\right\} \times 100$

ここで、 $\Delta \boldsymbol{w}_{0}$ : 質量減少率 $(\%)$

$\mathrm{W}_{0} \quad$ ：最初の鉄筋の質量（g）

$\mathrm{W}$ ：暴露試験後に錆落しをした鉄筋の質量 $(\mathrm{g})$

なお、クエン酸 2 アンモニウム水溶液により錆を除去する際、健 全な鉄筋表面の不動態被膜（以下、黒皮）が除去される。そこで、 除去される鉄筋の黒皮の質量百分率 $w_{\mathrm{s}}$ を、ダミ一鉄筋を用いて同 様の処理を行って求め、質量減少率を補正することが必要となる。 既報 ${ }^{8)}$ の屋外暴露期間 9 年までの結果については、別途測定した值 の平均值 $0.52 \%$ を補正值としている。しかし、屋外暴露試験が長期 間にわたると、各屋外暴露期間での測定において、測定者が異なる ことや鉄筋の錆の状況により、クエン酸 2 アンモニウム水溶液への 浸せき時間や錆の除去方法に差が生じる可能性がある。そのため、 各屋外暴露期間で除去される鉄筋の黒皮の質量百分率 $w_{\mathrm{s}}$ にも、ば らつきが生じると考えられる。そこで、図 2 に示すとおり、各屋外 暴露期間における発錆面積率が $10 \%$ 以下の場合の発錆面積率と質 量減少率との関係を確認することとした。屋外暴露期間 2 年、 5 年 での発錆面積率が約 $2 \%$ 以下の範囲での質量減少率は、既報 8$)$ で用い
た補正值である $0.52 \%$ に近い值を示しているが、 9 年目では $0.8 \%$ 程 度であり、既報 ${ }^{8)}$ の補正值より大きな值となっている。また、 15 年、 20 年での質量減少率は、大きくばらついており、発錆面積率が 3 4\%を超えると大きくなる傾向にある。

以上のことから本実験では、除去されたと想定される鉄筋の黒皮 の質量百分率 $w_{\mathrm{s}}$ を、各屋外暴露期間ごとに求めることとした。そ こで、表 4 に示すとおり、発錆面積率 $2 \%$ 以下の質量減少率の平均 值を算出し、除去されたと想定される鉄筋の黒皮の質量百分率 $\boldsymbol{w} \mathrm{s}$ として、式（2）を用いて補正質量減少率 $\Delta \boldsymbol{w}$ を求めた。なお、事 前に発錆面積率 $2 \%$ おび $3 \%$ でそれぞれについて数值を検討し たが大きな変動は見られなかった。

表 4 除去されたと想定される鉄筋の黒皮の質量百分率 $\boldsymbol{w}_{\mathrm{s}}$

\begin{tabular}{c|c|c|c|c|c}
\multicolumn{5}{c|}{ と標準偏差 } \\
\cline { 2 - 6 } & \multicolumn{5}{|c}{ 屋外暴露期間 (年) } \\
\cline { 2 - 6 } & 2 & 4 & 9 & 15 & 20 \\
\hline \hline$w_{\mathrm{s}}(\%)$ & 0.58 & 0.37 & 0.82 & 0.99 & 0.82 \\
\hline 標準偏差 & 0.017 & 0.032 & 0.038 & 0.141 & 0.165 \\
\hline
\end{tabular}




\section{3. 試験結果}

$\Delta \boldsymbol{w}=\Delta \boldsymbol{w}_{0}-\left(\boldsymbol{w}_{\mathrm{s}} \times(100-\mathrm{s}) / 100\right) \cdots \cdots(2)$

3.1 ひび割れ幅、発錆面積率、質量減少率および補正質量減少率

表 5 に各屋外暴露期間におけるひび割れの有無と幅、発錆面積率、 質量減少率および補正質量減少率を示す。

$\Delta \boldsymbol{w}_{0}$ : 質量減少率 $(\%)$

$w_{\mathrm{s}}$ : 除去されたと想定される鉄筋の黒皮の質量

3.2 コンクリートの中性化深さと塩化物イオン量 百分率 $(\%)$

$\mathrm{S} \quad$ : 発錆面積率 $(\%)$

コンクリートの中性化深さは、暴露期間 9 年までは、最小かぶり である $15 \mathrm{~mm}$ にはいずれも達していないが、屋外暴露期間 15 年以 降では $15 \mathrm{~mm}$ を超えるものがあった。

表 5 各屋外暴露期間におけるひび割れ幅、発錆面積率、質量減少率および補正質量減少率

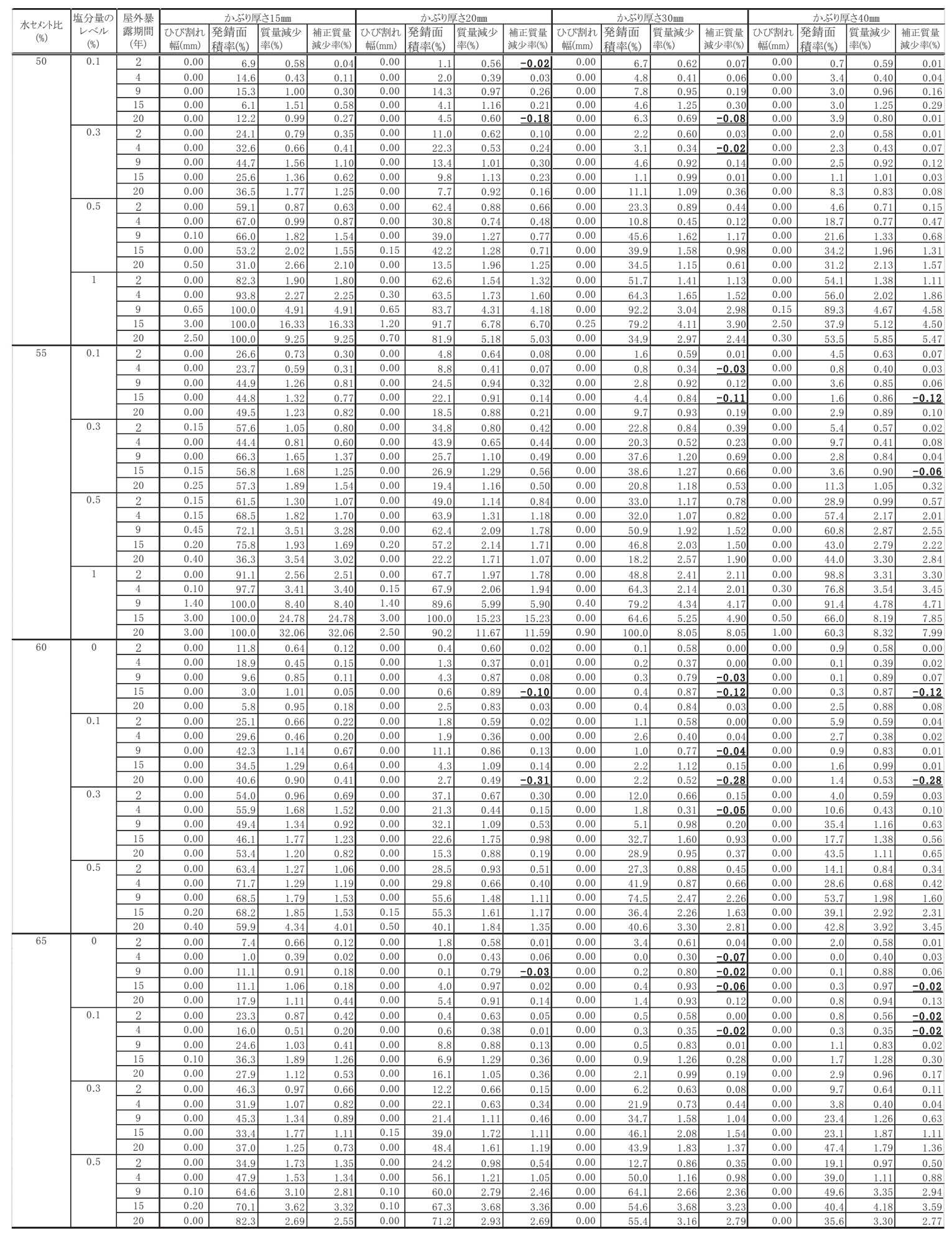




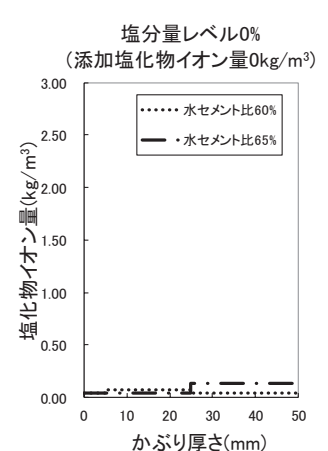

ふり厚さ (mm)

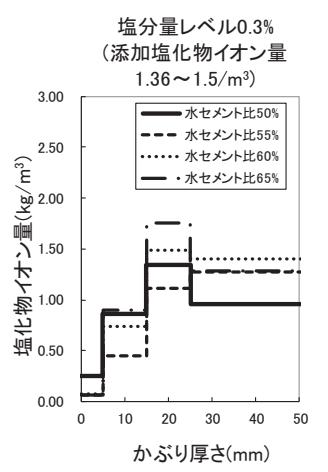

図 3 屋外暴露期間 20 年のコンクリート中の塩化物イオン量

しかし、後述する図 6 の中でみられるように、鉄筋腐食に対する影 響は、ほとんどなかった。

図 3 に、屋外暴露期間 20 年におけるコンクリート中の塩化物イ オン量を示す。表層部は、中性化による移動あるいは雨水等の影響 での流出により小さい值を示すが、鉄筋が存在するかぶり厚さ $15 \mathrm{~mm}$ より深い部分については、塩分量レベル 0 から $0.5 \%$ の範囲 では、概ね添加塩化物イオン量に近い值を示している。塩分量のレ ベル $1.0 \%$ にいては、混入塩化物イオン量より小さい值を示すが、 この理由については、別途検討することとする。

\section{4. 考察}

\section{1 補正質量減少率に影響するひび割れ幅}

コンクリートにひび割れが発生すると、鉄筋の腐食は急激に進行 することが指摘されている。そこで、かぶり厚さ別にひび割れ幅と 補正質量減少率の関係を調べた。その結果は図 4 に示寸とおりであ る。ひび割れが発生していない場合の補正質量減少率の最大值は、 かぶり厚さ $15 \mathrm{~mm}$ では $2.55 \%$ 、かぶり厚さ $20 \mathrm{~mm}$ では $2.69 \%$ 、か ぶり厚さ $30 \mathrm{~mm}$ では $4.90 \%$ 、かぶり厚さ $40 \mathrm{~mm}$ では $4.71 \%$ であ、 かぶり厚さが大きくなるに伴い、補正質量減少率の最大值は大きく なっている。このことから、かぶり厚さ $30 \mathrm{~mm}$ および $40 \mathrm{~mm}$ の場 合、かぶり厚さ $15 \mathrm{~mm}$ および $20 \mathrm{~mm}$ よりも、ひび割れが生じた時 点での鉄筋の腐食がかなり進行しているものが多くあると考えられ る。また、かぶり厚さ $15 \mathrm{~mm}$ 就よ゙ $20 \mathrm{~mm}$ では、ひび割れ幅が 0.5 $\mathrm{m} m$ を超えると補正質量減少率が $5 \%$ 以上になるものが多くみられ るが、かぶり厚さ $30 \mathrm{~mm}$ 拈よ゙ $40 \mathrm{~mm}$ では、ひび割れ幅が $0.3 \mathrm{~mm}$ を超えると補正質量減少率が $5 \%$ 以上になるものがある。このこと から、ひび割れ発生後も、鉄筋のかぶり厚さにより鉄筋の腐食の度 合いが異なることがわかる。
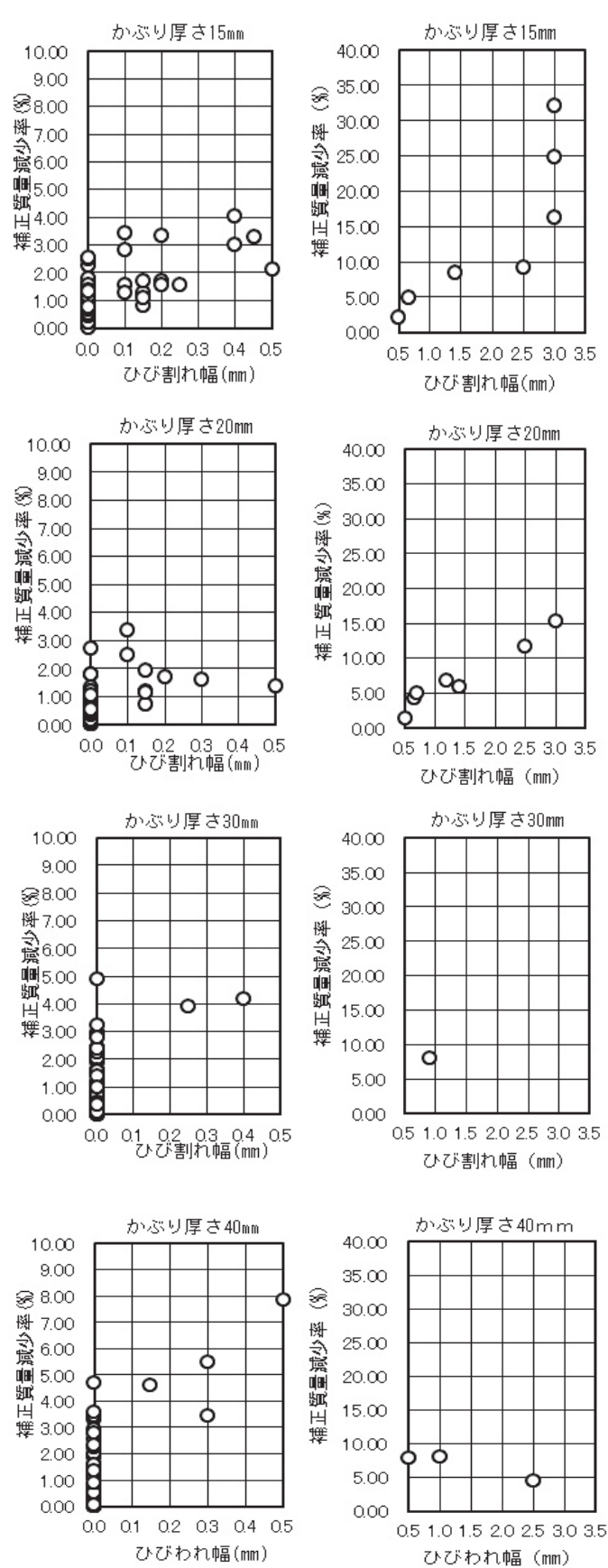

図 4 各かぶり厚さ別のひび割れ幅と補正質量減少率の関係

ひび割れ幅が $0.2 \mathrm{~mm}$ までの補正質量減少率は、ひび割れなしの ものより小さい值を示しているものが多くある。既報 7)8では、ひび 割れ幅が $0.1 \mathrm{~mm}$ 以上となると鉄筋の質量が非常に大きくなってい ることから、 $0.1 \mathrm{~mm}$ 以上の鉄筋の質量減少率を腐食速度の評価の際 に除外している。しかし、本実験での結果からは、ひび割れ幅 $0.2 \mathrm{~mm}$ までは、鉄筋の補正質量減少率が大きいものは比較的少ない。「コン クリートのひび割れ調查、補修・補強指針」9)によれば、コンクリ 一ト中の鋼材腐食に及ぼすひび割れ幅の部材性能への影響に関して は、ひび割れ幅 $0.2 \mathrm{~mm}$ 以下では影響が小さいとしている。これら のことを考慮して、ここでは、外部から塩化物イオンの浸入がない 条件での屋外暴露試験におけるコンクリート中の鉄筋腐食速度を補 
正質量減少率で評価する場合、ひび割れ幅 $0.2 \mathrm{~mm}$ 以下を対象とす ることとし、以後、考察することとした。

\section{2 腐食傾向定数と暴露開始までの期間}

一般に、コンクリート中の鉄筋の腐食速度係数の指標としては発 錆面積率と質量減少率が挙げられるが、既報 8 )において、質量減少 率を指標と寸ることが適当であるとして用いており、ここでも、補 正質量減少率を用いて鉄筋腐食速度を解析し、評価することとした。 また、補正質量減少率がマイナスの值のものも、発錆が認められて いることを考慮して0とした。暴露期間と質量減少率を用いた腐食 速度係数については、他の多くの研究 3 (5) 77 ) および既報 8 )の屋外暴露 期間 9 年までの結果において、直線関係として解析を行っているが、 本実験での暴露期間 15 年および 20 年でのデータを加えてみたとこ ろ、全体として、暴露期間 9 年までは、暴露期間の経過に伴い補正 質量減少率は直線的に増加量する傾向であるが、それ以降は増加の 割合が小さくなっており、傾向が異なっている。また、鉄筋の腐食 は、屋外暴露試験開始までの前養生および中性化促進試験を実施し ている期間に進行していることが考えられる。そこで、補正質量減 少率 $\Delta \boldsymbol{w}$ と屋外暴露期間 $t$ に試験体製作後の屋外暴露開始までの期 間 $t o$ を加えた、いわゆる等価な暴露期間の関係を最小二乗法によ り、式(3)で近似し、腐食傾向定数 $b$ を求めることとした。なお、屋 外暴露開始までの期間 $t$ 。は既報 7 )の促進試験では $2 / 12$ 年 ( 2 力月) としており、実際に暴露試験を開始したのが試験体製作後 $9 / 12$ 年 $(9$ カ月）であるので、それぞれについて検討した。

$$
\Delta \boldsymbol{w}=q^{\prime}\left(t+t_{0}^{\prime}\right)^{b}
$$

ここで、 $\Delta \boldsymbol{w}$ : 補正質量減少率 $(\%)$

$$
\begin{aligned}
q^{\prime} & : \text { 腐食速度係数 }(\% / \text { 年 } 1 / \mathrm{b}) \\
t & : \text { 屋外暴露期間 }(\text { 年) } \\
t_{0}^{\prime} & : \text { 試験体製作後、屋外暴露開始までの期間(年) } \\
b & : \text { 腐食傾向定数 }
\end{aligned}
$$

図 5 には、 $t_{0}=2 / 12$ 年 $(2$ 力月) として、得られた腐食傾向定数 $b$ を、水セメント比ごと、かぶり厚さごとおよび塩分量のレベルご とのそれぞれの值と中央值を示す。いずれもばらつきはあるが、そ れぞれ中央值は、概ね 0.5 となっている。また、 $t_{0}=9 / 12$ 年 $(9$ 力 月）についても、それぞれの中央値は 0.5 に近い值であった。すな わち、補正質量減少率は、等価な暴露期間 $(t+t o)$ の平方根に比例 すると考えられる。

鉄筋の腐食が酸素と水分の供給量に比例するとすれば、鉄筋位置に 拡散してくる酸素の蓄積量は時間に比例するため、腐食量も時間に
比例することになるが、今回の結果からは、時間に比例していない。 この傾向と類似の傾向を示寸研究 10-11) もあり、腐食量は必ずしも経 過年数に比例し直線的に増加するわけではないと考えられる。

この理由として、鉄筋腐食に伴い、鉄筋表面に生成される錆層の 影響が考えられる。鉄筋腐食が進行すると錆層ができ、健全な鉄筋 表面へ酸素あるいは水が接触するためには、錆の層を通過すること から腐食速度が変化すると考えられる。その場合の錆の層の影響に よる腐食速度の変化は、コンクリートの中性化進行での状況と同様 であると考えられる。

次に、腐食傾向定数 $b=0.5$ として、式(4)を用いて最小二乗法に より、 $t_{0}$ を求めることとした。

$$
\Delta \boldsymbol{w}=q\left(t+t_{0}\right)^{0.5}
$$

ここで、 $\Delta \boldsymbol{w}$ : 補正質量減少率(\%)

$q:$ 腐食速度係数 $(\% / \sqrt{ }$ 年 $)$

$t:$ 暴露期間(年)

$t_{0}:$ 試験体製作後、屋外暴露開始までの期間(年)

その結果、 $t o$ は、ばらつきが非常に大きく、負の值や最長期間の $9 / 12$ 年 (9 カ月) より大きな值を示寸ものが見られた。そこで、負 の值は 0 とし、最長期間の $9 / 12$ 年 ( 9 カ月) より大きな值は、 $9 / 12$ 年 $\left(9\right.$ カ月) として、 $t_{0}$ の平均值および中央値をみると、平均值は $3.7 / 12$ 年 (3.7 カ月)、中央值は $3.2 / 12$ 年 (3.2 カ月) であった。こ こでは、鉄筋腐食開始から屋外暴露開始までの期間 $t_{0}$ を前述の中 央値の $3.2 / 12$ 年 (3.2 力月) とすることとした。これは、促進中性 化期間および恒温恒湿室に保存した期間の 9 カ月が、大略、屋外暴 露期間 3.2/12 年 (3.2 力月)に相当するとしたことを意味している。

\section{3 屋外暴露期間と補正質量減少率の関係}

図 6 には、屋外暴露期間と補正質量減少率の関係と鉄筋腐食開始 から屋外暴露開始までの期間 $t_{0}$ を $3.2 / 12$ 年（3.2 力月）、腐食傾向 定数 0.5 として、最小二乗法で回帰した曲線を示す。図中では、ひ び割れ幅 $0.2 \mathrm{~mm}$ 以下と $0.2 \mathrm{~mm}$ を超える場合とを区別して示した。 いずれの暴露期間においても、塩分量のレベルが高いほど、補正質 量減少率は大きな值を示している。表 6 に各条件ごとの腐食速度係 数 $q$ の算定結果を、図 7 には回帰より得られた腐食速度係数とかぶ り厚さの関係を示す。腐食速度係数は、塩分量のレベルが 0 から $0.3 \%$ 範囲では、かぶり厚さが大きくなるに伴って小さくなる傾向 にある。一方、塩分量のレベルが $0.5 \%$ 以上では、かぶり厚さ $15 \mathrm{~mm}$ における腐食速度係数と、かぶり厚さが $40 \mathrm{~mm}$ の場合とほぼ同程度 の值を示している。この理由としては、塩分量のレベル $0.5 \%$ 以上
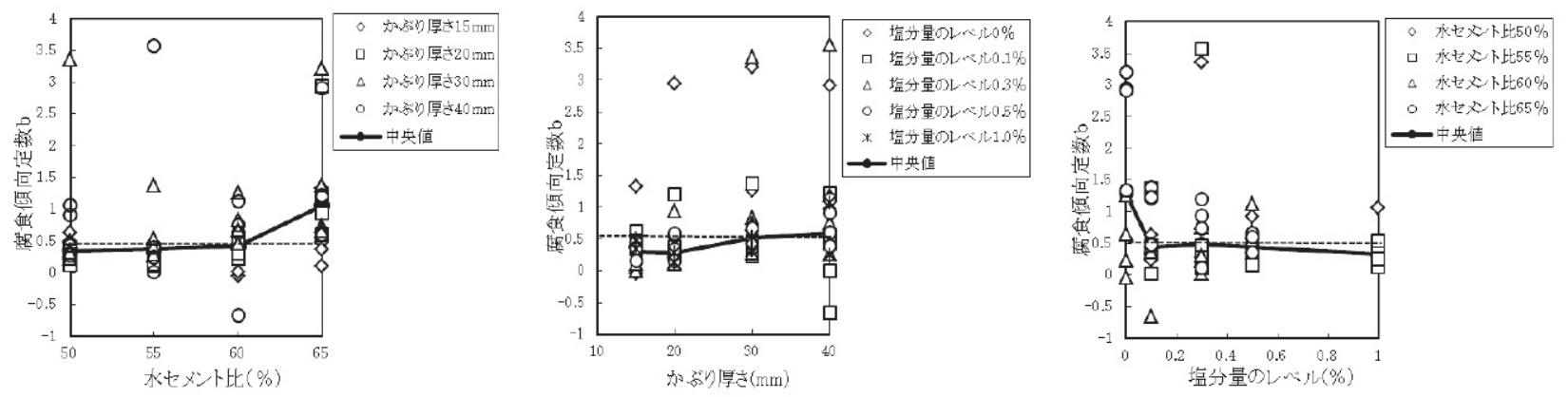

図 5 各種要因と腐食傾向定数 $\mathrm{b}$ の関係 $\left(t_{0}=2\right.$ 力月の場合 $)$ 


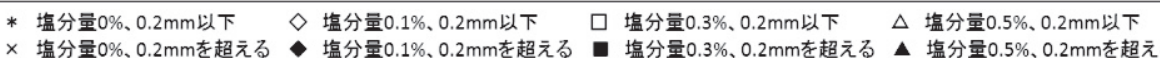

○塩分量 $1.0 \%, 0.2 \mathrm{~mm}$ 以下

㙁分量 $1.0 \%, 0.2 \mathrm{~mm}$ 超云る
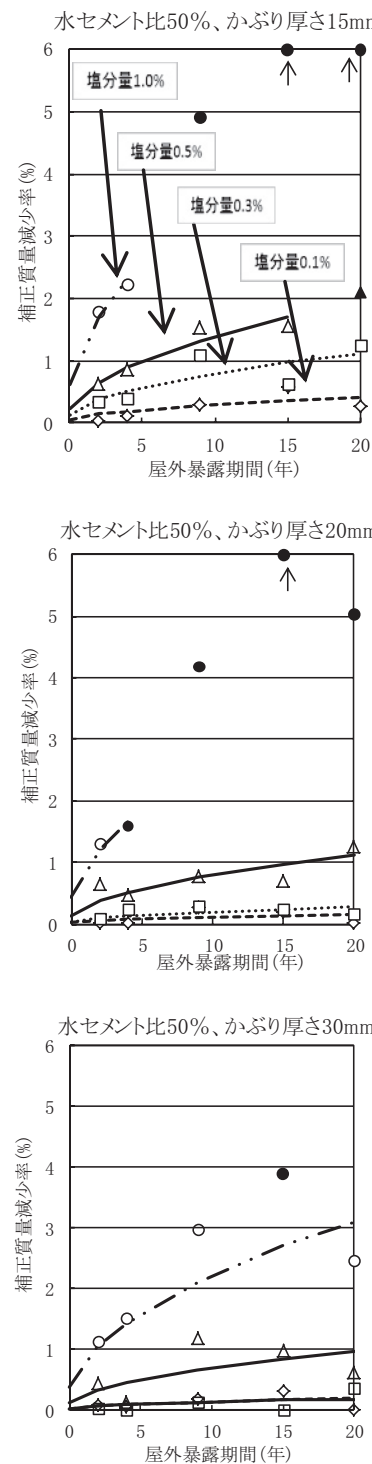

水セメント比 $50 \%$ 、かぶり厚さ $40 \mathrm{~mm}$

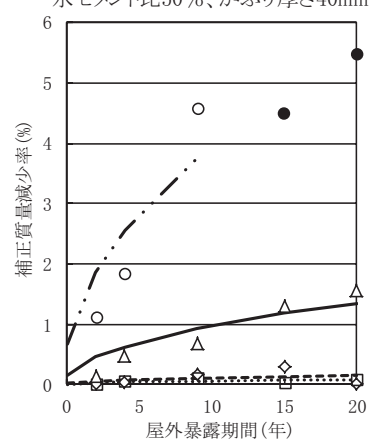

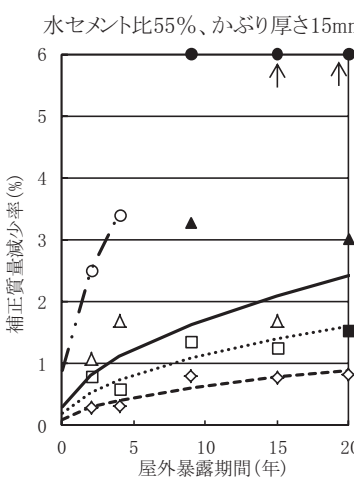
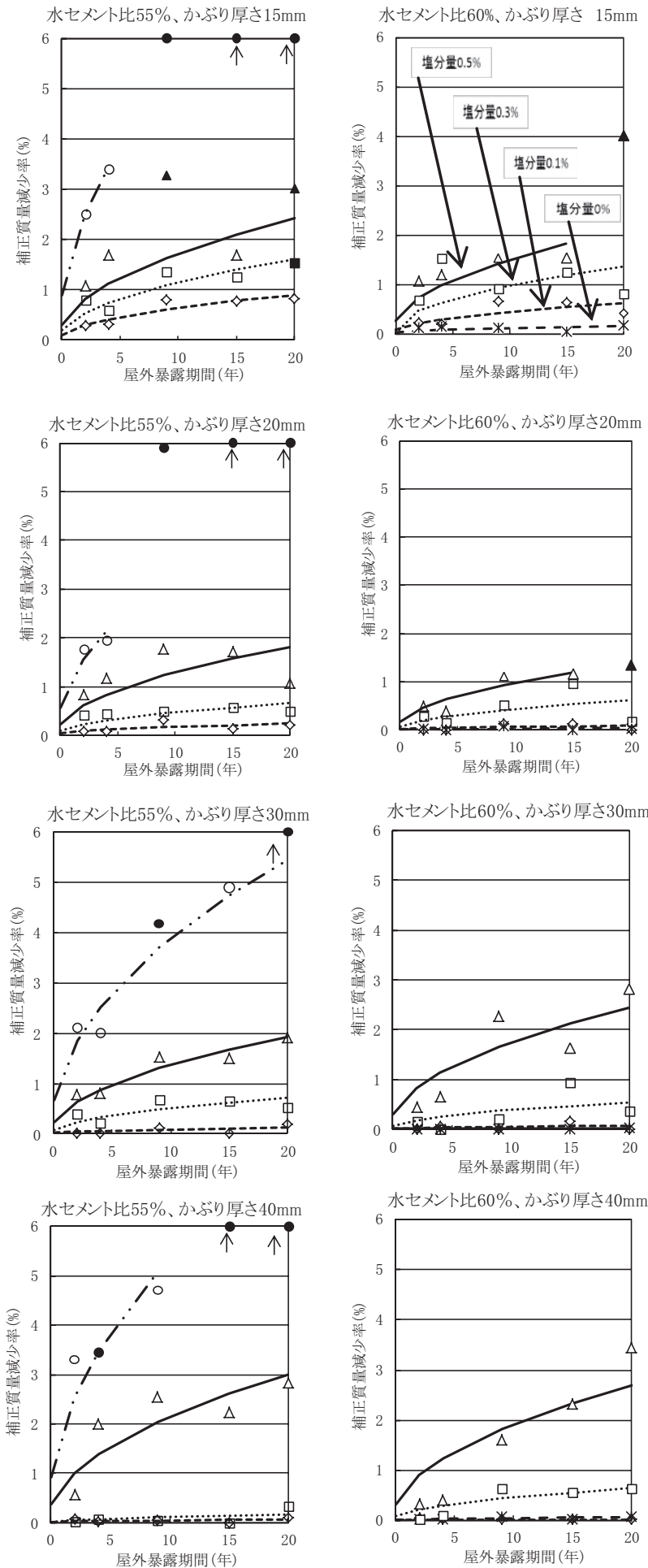

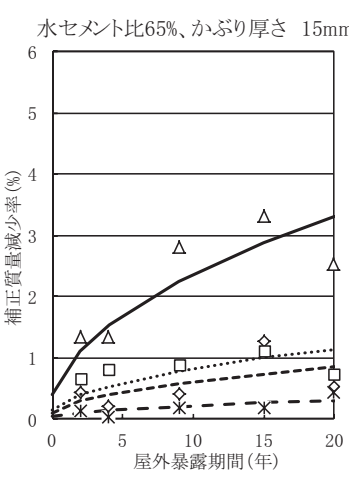

水セメント比 $65 \%$,かぶり厚さ $20 \mathrm{~mm}$

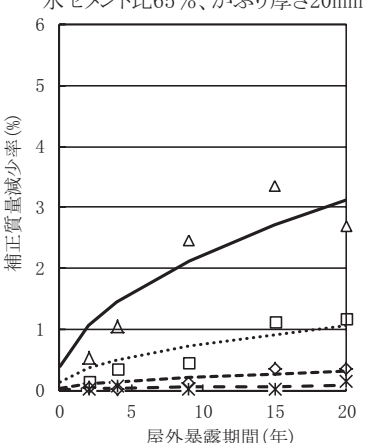

水セxント比 $65 \%$,かぶり厚さ $30 \mathrm{~mm}$

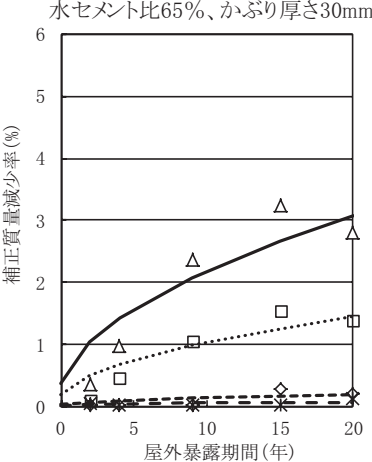

水セメント比 $65 \%$ 、かぶり厚さ $40 \mathrm{~mm}$

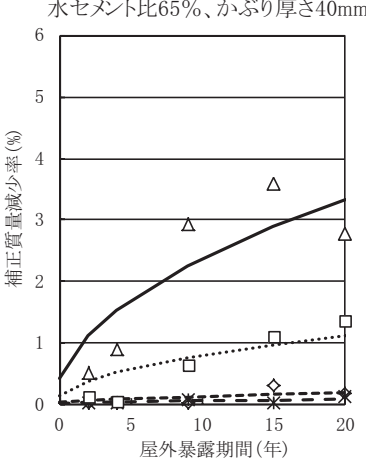

図 6 屋外暴露期間と鉄筋の補正質量減少率の関係

で、かぶり厚さが $40 \mathrm{~mm}$ の場合、ひび割れが発生しにくく、補正質 量減少率の值の大きいものが腐食速度係数の解析に反映されている が、かぶり厚さ $20 \mathrm{~mm}$ 以下の場合は、早い時期にひび割れが発生し、 その時期の特定が困難であり、質量減少率の值が比較的小さいもの の值が腐食速度係数の解析に反映されたため、ばらつきがあること が考えられる。

\section{4 腐食速度係数推定式}

腐食速度係数は、一般に、かぶり厚さが大きくなるに伴い減少す る傾向にある。そこで、図 7 に示寸腐食速度係数 $q$ とかぶり厚さ $\mathrm{C}$ の関係を、式(5)で最小二乗法により近似し、係数 $\beta$ を求めた。その 結果を表 7 に示す。 
表 6 各条件ごとの腐食速度係数の算定結果 $(\% / \sqrt{ }$ 年)

\begin{tabular}{|c|c|c|c|c|c|c|}
\hline \multirow{2}{*}{$\begin{array}{l}\text { 水セメン } \\
\text { 卜比 }(\%)\end{array}$} & \multirow{2}{*}{$\begin{array}{l}\text { かぶり厚 } \\
\text { さ }(\mathrm{mm})\end{array}$} & \multicolumn{5}{|c|}{ 塩分量のレベル (\%) } \\
\hline & & 0 & 0.1 & 0.3 & 0.5 & 1.0 \\
\hline \multirow{4}{*}{50} & 15 & - & 0.090 & 0.249 & 0.434 & 1.119 \\
\hline & 20 & - & 0.034 & 0.062 & 0.248 & 0.805 \\
\hline & 30 & - & 0.040 & 0.041 & 0.216 & 0.689 \\
\hline & 40 & - & 0.035 & 0.019 & 0.300 & 1.227 \\
\hline \multirow{4}{*}{55} & 15 & - & 0.199 & 0.357 & 0.537 & 1.645 \\
\hline & 20 & - & 0.053 & 0.146 & 0.402 & 1.019 \\
\hline & 30 & - & 0.025 & 0.158 & 0.426 & 1.211 \\
\hline & 40 & - & 0.016 & 0.035 & 0.666 & 1.670 \\
\hline \multirow{4}{*}{60} & 15 & 0.035 & 0.139 & 0.301 & 0.468 & - \\
\hline & 20 & 0.009 & 0.020 & 0.137 & 0.307 & - \\
\hline & 30 & 0.005 & 0.015 & 0.119 & 0.543 & - \\
\hline & 40 & 0.013 & 0.005 & 0.141 & 0.599 & - \\
\hline \multirow{4}{*}{65} & 15 & 0.067 & 0.187 & 0.253 & 0.735 & - \\
\hline & 20 & 0.016 & 0.069 & 0.234 & 0.694 & - \\
\hline & 30 & 0.014 & 0.039 & 0.319 & 0.679 & - \\
\hline & 40 & 0.017 & 0.039 & 0.245 & 0.739 & - \\
\hline
\end{tabular}
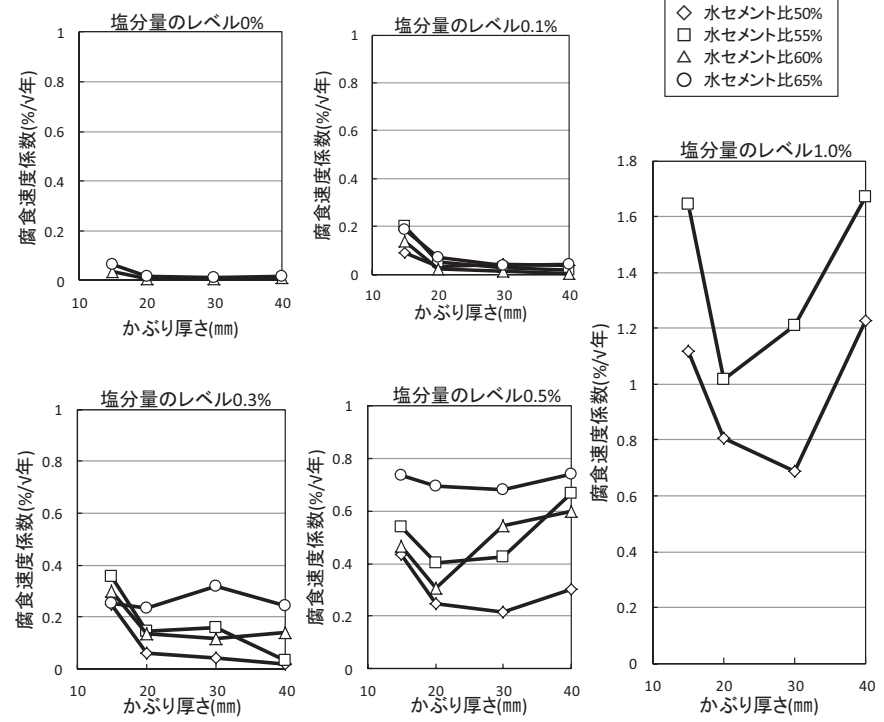

図 7 腐食速度係数とかぶり厚さの関係

$$
q=\alpha \cdot \mathrm{C}^{\beta}
$$

ここで、 $q$ : 腐食速度係数 $(\% / \sqrt{ }$ 年 $)$

$$
\mathrm{C}: \text { かぶり厚さ }(\mathrm{mm})
$$$$
\alpha 、 \beta: \text { 係数 }
$$

係数 $\beta$ の值が負でないものについては、腐食速度係数がかぶり厚 さの増大に伴う減少が見られないことから、0 として平均值を求め ている。係数 $\beta$ の平均值は、塩分量のレベルが $0 \%$ の場合、かぶり 厚さの約 1.9 乗に、塩分量レベルが $0.3 \%$ の場合、約 0.8 乗に、塩分 量のレベルが $0.3 \%$ の場合、約 0.6 乗に、塩分量のレベルが $0.5 \%$ の 場合、約 0.2 乗に反比例している。また、塩分量のレベルが $1.0 \%$ の 場合には、0 となり、かぶり厚さが 15〜 $40 \mathrm{~mm}$ の範囲では腐食速度 係数に与える影響が少ないといえる。一方、水セメント比と係数 $\beta$ との関係は一定の傾向がみられない。

図 8 には、かぶり厚さと $\mathrm{C}^{\beta}$ の関係を示す。塩分量のレベルが大 きくなるに伴い、腐食速度係数に及ぼすかぶり厚さの影響は小さく なる傾向になっている。
表 7 係数 $\beta$ の値

\begin{tabular}{c|c|c|c|c|c}
\hline \multirow{2}{*}{$\begin{array}{c}\text { 水セメン } \\
\text { ト比(\%) }\end{array}$} & \multicolumn{5}{|c}{ 塩分量のレベル $(\%)$} \\
\cline { 2 - 6 } & 0 & 0.1 & 0.3 & 0.5 & 1.0 \\
\hline \hline 50 & - & -0.66 & -0.89 & -0.47 & $(0.07)$ \\
\hline 55 & - & -1.11 & -0.74 & -0.14 & $(0.09)$ \\
\hline 60 & -1.97 & -0.67 & -0.60 & 0 & - \\
\hline 65 & -1.82 & -0.81 & -0.30 & -0.10 & - \\
\hline 平均値 & -1.90 & -0.81 & -0.63 & -0.18 & 0 \\
\hline
\end{tabular}

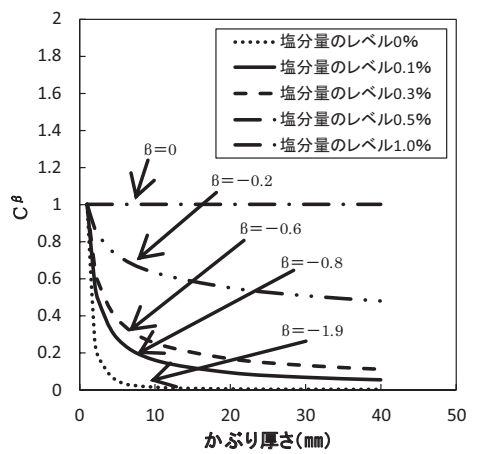

図 8 かぶり厚さと $\mathrm{C}^{\beta}$ の関係

腐食速度とかぶり厚さの関係について、森永 3 の暴露試験では、 腐食速度はかぶり厚さの 2 乗に反比例するとしており、松林ら 7の 促進試験では、腐食速度はかぶり厚さの平方根に反比例するとして いる。腐食速度が鉄筋の位置に達する酸素の量に比例するとすれば、 理論的にかぶり厚さに反比例することになるが、本実験での係数 $\beta$ の值からみると、腐食速度に及ぼすかぶり厚さの影響は、塩分量の レベルにより異なり、塩分量が少ない場合は森永式に、多い場合は 松林式に近づき、更に多い場合は、かぶり厚さの影響がかぶり厚さ $40 \mathrm{~mm}$ 以内の範囲でなくなるといえる。

表 8 には、塩分量のレベルごとの係数 $\beta$ の平均值を用いて、式 (5) によって求めた係数 $\alpha$ の值を示す。係数 $\alpha$ は、概水水セメント比が 大きくなるに伴い大きくなる傾向にある。なお、水セメント比 $55 \%$ と $60 \%$ とで值が逆転しているが、これは、当初の試験体作製時の誤 差であったと考えている。

表 8 係数 $\alpha$ の值

\begin{tabular}{c|c|c|c|c|c}
\hline \multirow{2}{*}{$\begin{array}{c}\text { 水セメン } \\
\text { ト比(\%) }\end{array}$} & \multicolumn{5}{|c}{ 塩分量のレベル(\%) } \\
\cline { 2 - 6 } & 0 & 0.1 & 0.3 & 0.5 & 1.0 \\
\hline \hline 50 & - & 0.62 & 0.70 & 0.57 & 0.96 \\
\hline 55 & - & 1.06 & 1.25 & 0.95 & 1.39 \\
\hline 60 & 5.27 & 0.66 & 1.19 & 0.89 & - \\
\hline 65 & 9.90 & 1.13 & 1.65 & 1.34 & - \\
\hline
\end{tabular}

係数 $\alpha$ と水セメント比の関係を最小二乗法により直線近似して求 めた式を、式（5）に代入すると腐食速度係数の推定式は、式（6） から（10）で表すことができる。

塩分量のレベル $0 \%$

(添加塩化物イオン量 $0 \mathrm{~kg} / \mathrm{m}^{3}$ )

$$
\begin{aligned}
q & =1 / \mathrm{C}^{1.9}(0.927 \mathrm{~W} / \mathrm{C}-50.3) \\
& =0.927 / \mathrm{C}^{1.9}(\mathrm{~W} / \mathrm{C}-54.3)
\end{aligned}
$$


塩分量のレベル $0.1 \%$

(添加塩化物イオン量 $0.45 \sim 0.52 \mathrm{~kg} / \mathrm{m}^{3}$ )

$$
\begin{aligned}
q & =1 / \mathrm{C}^{0.8}(0.023 \mathrm{~W} / \mathrm{C}-0.43) \\
& =0.023 / \mathrm{C}^{0.8}(\mathrm{~W} / \mathrm{C}-18.7)
\end{aligned}
$$

塩分量のレベル $0.3 \%$

(添加塩化物イオン量 $1.36 \sim 1.55 \mathrm{~kg} / \mathrm{m}^{3}$ )

$$
\begin{aligned}
q & =1 / \mathrm{C}^{0.6}(0.056 \mathrm{~W} / \mathrm{C}-2.00) \\
& =0.056 / \mathrm{C}^{0.6}(\mathrm{~W} / \mathrm{C}-35.7)
\end{aligned}
$$

塩分量のレベル $0.5 \%$

(添加塩化物イオン量 $2.27 \sim 2.58 \mathrm{~kg} / \mathrm{m}^{3}$ )

$$
\begin{aligned}
q & =1 / \mathrm{C}^{0.2}(0.045 \mathrm{~W} / \mathrm{C}-1.55) \\
& =0.045 / \mathrm{C}^{0.2}(\mathrm{~W} / \mathrm{C}-34.4)
\end{aligned}
$$

塩分量のレベル $1.0 \%$

(添加塩化物イオン量 $4.54 \sim 4.68 \mathrm{~kg} / \mathrm{m}^{3}$ )

$$
\begin{aligned}
q & =1 / \mathrm{C}^{0}(0.085 \mathrm{~W} / \mathrm{C}-3.30) \\
& =0.085 / \mathrm{C}^{0}(\mathrm{~W} / \mathrm{C}-38.8)
\end{aligned}
$$

ここで、 $q$ : 腐食速度係数 $(\% / \sqrt{ }$ 年 $)$

$\mathrm{C}$ : かぶり厚さ $(\mathrm{mm})$

$\mathrm{W} / \mathrm{C}:$ 水セメント比 $(\%)$

これらの式をみると、塩分量のレベルが $0 \%$ ときは、水セメン 卜比が $54.0 \%$ 程度以下で、塩分量のレベル $0.3 \sim 1.0 \%$ のきは、水 セメント比が $35.0 \%$ 程度以下で腐食速度係数は 0 となる。

図 8 には、式（6）から（10）を用いて計算した腐食速度係数の 推定值と実験值の関係を示すが、塩分量のレベル $0.3 \%$ までは比較的 よく近似されているが、塩分量のレベル 0.5 および 1.0 では、ばら つきが大きくなっていることがわかる。

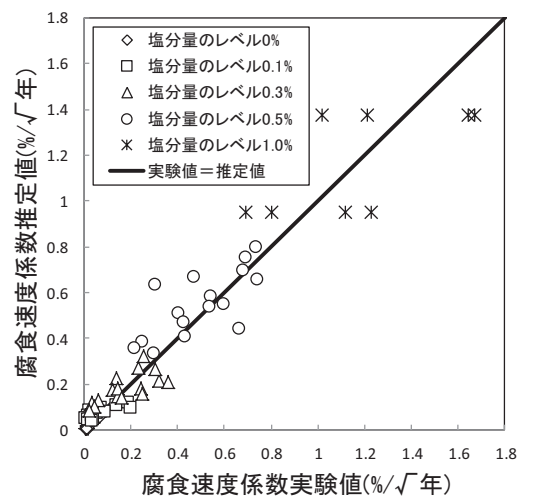

図 9 腐食速度係数の推定值と実験值の関係

\section{5. 結 論}

本実験は、水セメント比を 50～65\% 、塩分量のレベルを $\mathrm{NaCl} /$ 砂質量比で 0 1. $0 \%$ （添加塩化物イオン量 $0 \sim 4.68 \mathrm{~kg} / \mathrm{m}^{3}$ ) のコン クリート中に、かぶり厚さを 15〜40mm で鉄管を埋め込んだ試験体を 用いて、 20 年間屋外暴露実験を行い、ひび割れ幅 $0.2 \mathrm{~m}$ m以下の鉄 筋の補正質量減少率を用いて鉄筋腐食速度を評価したものである。 本実験の範囲では、以下のようにまとめられる。

（1）ひび割れが発生していない場合の補正質量減少率の最大值は、 かぶり厚さが大きくなるに伴い、大きくなる傾向にある。

(2) 鉄筋の補正質量減少率は、既報 8)の屋外暴露期間 9 年までの場
合には暴露期間の増加に伴い直線的に増加する傾向にあった が、暴露期間 15 年および 20 年までの結果を加えると屋外暴露 期間の平方根に比例する傾向にある。

（3）鉄筋腐食速度係数は、塩分量のレベル 0 0.3\%では、かぶり厚 さが大きくなるに伴い、小さくなる傾向にある。

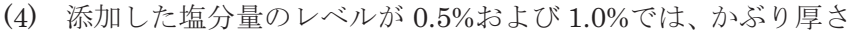
$15 \mathrm{~mm}$ における腐食速度係数は、かぶり厚さ $40 \mathrm{~mm}$ ものとほ ぼ同程度の值を示している。

（5）鉄筋腐食速度係数に及ぼすかぶり厚さの影響は、塩分量のレベ ルにより異なる。

（6）水セメント比を 50 ～65\%、塩分量のレベルを $\mathrm{NaCl} /$ 砂質量比 で 0 1.0\%（添加塩化物イオン量 $0 \sim 4.68 \mathrm{~kg} / \mathrm{m}^{3}$ ) の範囲での 屋外暴露における鉄筋の腐食速度係数は、式（6）から（10） で表される。

\section{参考文献}

1）李 榮蘭, 桝田佳寛, 掛川 勝: 塩化物を含んだコンクリート中の鉄筋 腐食に及ぼす各種要因の影響その 1 実験, 日本建築学会大会学術講演梗 概集 A-1 材料施工，pp. 1287-1288，2010.8

2）掛川 勝，桝田佳寛，李 榮蘭: 塩化物を含んだコンクリート中の鉄筋 腐食に及ぼす各種要因の影響 その 2 解析, 日本建築学会大会学術講 演梗概集 A-1 材料施工，pp. 1289-1290，2010.8

3）森永 繁：鉄筋の腐食速度に基づいた鉄筋コンクリート建築物の寿命予 測に関する研究，東京大学学位請求論文，1986.11

4） コンクリート専門委員会報告 F-33 ：海砂の塩分含有量とコンクリート 中の鉄筋の発錆に関する研究, セメント協会, 1981.3

5）友沢史紀, 桝田佳寛, 阿部道彦, 田中斉, 安田正雪他 : 鉄筋コンクリー 卜造建築物の塩害実態調查, 建築研究報告, No. 118, 1981.11

6）建設省総合技術開発プロジェクト報告書：コンクリートの耐久性向上技 術の開発，建設省，1988.11

7）桝田佳寛, 花栄 浩, 松林裕二, 原謙治, 安田正雪 : 塩化物を含んだコ ンクリート中の鉄筋腐食速度に関する実験、日本建築学会構造系論文報 告集，第 435 号，pp. 19-27，1992.5

8）松林裕二, 桝田佳寛, 笹㴊優樹：塩化物を含んだコンクリート中の鉄筋 腐食速度に関する屋外暴露実験、日本建築学会構造系論文集, 第 536 号, pp. $9-15,2000.10$

9）社団法人日本コンクリート工学協会：コンクリートのひび割れ調查、補 修・補強指針－2009 - , 2009.3

10）岩田亮，Qi Lukuan, 関 博：中性化したコンクリート中における鉄筋 腐食機構の電気化学的考察, コンクリート工学年次論文集 Vol. 22, №. 1, pp. 181-186, 2000. 6

11）西村眞治他 3 名：長期暴露試験体の鉄筋質量減少率に基づく断面修復工 の補修効果の評価, 日本建築学会構造系論文集, 第 75 巻, 第 655 号, pp. 1601-1608, 2010.9

(2011年 6 月 8 日原稿受理，2011年10月25日採用決定） 